\title{
Fungal Hosts of Fungivorous Tenebrionid Beetles (Tenebrionidae) in Korea
}

\author{
Boo Hee Jung* and Jong Wook Lee \\ Department of Life Science, Yeongnam University, Gyeongsan-si, 712-749, Korea \\ 한국산 균식성 거저리의 숙주버섯 \\ 정부희 $\cdot$ 이종욱 \\ 영남대학교
}

\begin{abstract}
We present a list of Korean fungivorous Tenebrionidae associated with higher fungi (Basidiomycetes). Most fungivorous tenebrionids are associated with the order Aphyllophorales. A total of 31 Tenebrionid species (both adults and larvae) belonging to four tribes (Bolitophagini, Toxicini, Scaphidemini, and Diaperini) are presented in our checklist. Of these, 62 percent are obligate mycetobionts, In addition, 42 fungal hosts of fungivorous tenebrionids are presented. Both thetenebrionids and the fungal hosts reported here are found throughout Korea.
\end{abstract}

Key words: Fungivorous tenebrionids, Bolitophagini, Toxicini, Scaphidemini, Diaperini, Fungal host

초 록: 한국산 균식성 거저리가 서식하는 숙주버섯의 종류 및 기주와의 관계를 정리하였다. 대부분의 한국산 균식성 거저리는 담자균강 가운데 민주름버섯류를 숙주버섯으로 선택하였다. 한국산 균식성 거저리는 모두 4개족(가시거저리족, 뿔거저리족, 뾰족날개거저리족, 르위스거저리족) 31 종으로 조사되었으며, 이 균식성 종들이 각각 서식하는 숙주버섯은 모두 42종으로 파악되었다. 한국 전역에 분포하는 31종의 균식성 거저리 목록과 균식성 거저리의 숙주버섯 목록을 제공하였다. 각 목록은 성충과 애벌레의 숙주버섯 이용 양상을 토대로 작성되었는데, 균식성 거저리의 약 $62 \%$ 가 균의존형(obligate mycetobionts)으로 밝혀졌다.

검색어: 한국산 균식성 거저리, 숙주버섯, 가시거저리족, 뿔거저리족, 뾰족날개거저리족, 르위스거저리족

Dead trees provide a rich habitat for a variety of fungi, including slime moulds, soft rots and the major groups of wood-rotting Ascomycetes and Basidiomycetes (Lawrence and Milner, 1996). In particular, woody and perennial forms of fungi of the order Aphyllophorales belonging to Basidiomycetes provide microhabitats in which many arthropod species spend their entire lives (Klimaszewski and Peck, 1987; Leschen, 1990; Jung and Kim, 2008). These fungi provide their inhabitants with food, shelter, and breeding places either directly or indirectly (Graves, 1960; Cline and Leschen, 2005).

*Comesponding author: starrylight12@hanmail.net

Received June 7 2011; Revised July 142011

Accepted July 272011
Some tenebrionid beetles have become specialized in feeding on macrofungi including Basidiomycetes and rarely Ascomycetes (Leschen, 1990). In particular, Basidiomycetes are the most commonly used foods of fungivorous tenebrionids. Basidiomycetes which serve as hosts for tenebrionids are composed mainly of two large groups - one of them is bracket fungi (order Aphyllophorales) which form spores within tubes and rarely on teeth and the other is mushrooms (order Agaricales) which form spores on gill or rarely within tubes. Most Aphyllophorales are ligneous and most Agaricales are soft (Breitenbach and Kränzlin, 1986; Kim et al., 2004; Leschen, 1990). Insects feeding on bracket fungi appear to be more host-specific than insects feeding on mushrooms. (Lawrence and Milner, 1996). 
Most fungivorous tenebrionids including five tribes (Bolitophagini, Toxicini, Scaphidemini, Diaperini, and Rhipidandrini) are observed to be obligatory inhabitants of longevous and woody bracket fungi. Both adults and larvae of fungivorous tenebrionids have spend their whole lives in the fruiting bodes of bracket fungi (Liles, 1956; Nadovornaya and Nadvornyy, 1991; Jung and Kim, 2008, 2009; Jung et al., 2009).

It is difficult to study the fungal host of fungivorous tenebrionids and other fungivorous beetles because they usually feed on the same sporophores until the fungi are completely destroyed and they also breed in the fruiting bodies of fungi, concealing their life histories (Jung and Kim, 2008). Thus, relatively few studies of the fungal hosts of tenebrionids have been published. Their fungal hosts have been partly reported through regional fauna, in taxonomic and biology papers in Europe (Benick, 1952; Nadvornaya and Nadvornyy, 1991; Nikitsky and Schigel, 2004; Krasutskii, 2006) and North America (Liles, 1956; Graves 1960; Heatwole and Heatwole, 1968; Matthewman and Pielow, 1971; Klimaczewski and Peck, 1987; Leschen 1990). However, those records do not correspond with Korean tenebrionid species. Until now only a small number of fungal hosts of tenebrionids have been reported as a part of taxonomic papers from Korea (Jung et al., 2007, 2009; Jung and Kim, 2008, 2009).

The purpose of this study is to report the fungal hosts of 31 Korean tenebrionid species belonging to the tribes Bolitophagini, Toxicini, Scaphidemini, and Diaperini. Host-fungi relationships were examined by rearing them in the laboratory and observing them in the field. Checklists of Tenebrionids associated with fungal hosts, and host records from the literature are also provided.

\section{Methods and Terminology}

\section{Sampling}

The host records cited in this paper are based on samples extracted in the field or laboratory from fruiting bodies collected and the host records from the literature. From 2005 to 2010, we collected 357 fruiting bodies of fungi associated with Korean tenebrionids throughout South Korea. To collect material effectively, we removed the host fungi from the substrate on the forest-floor with cloth or vinyl cloth and quickly transferred them into vinyl bags and sealed the bags. Eggs, larvae, and adults found on the fungi were brought to the laboratory and transferred to plastic containers or zippered vinyl bags, which were covered with black cloth to maintain darkness, and were subsequently sorted, identified, counted, and reared. All tenebrionids studied in this paper were reared in the laboratory in petri dishes (diameter $=9$ $\mathrm{cm}$, height $=1.5 \mathrm{~cm})$ at room temperature $\left(25.5 \sim 26.1{ }^{\circ} \mathrm{C}\right)$ and at a relative humidity of $63.5 \sim 64.5 \%$, and provided with pieces of the host fungus, which was collected with the tenebrionids together.

For example, when Playtdema nigroaeneum collected with fruiting body of Daedaleopsis tricolor in the field was brought to the laboratory, we provide $P$. nigroaeneum with $D$. tricolor during all its lives (Development from egg to adulthood took about 66 days in the laboratory at $25.5 \sim 26.1^{\circ} \mathrm{C}$ and $63.5 \sim$ $64.5 \%$ relative humidity). Subsequently $P$. nigroaeneum fed the 5 pieces of the fruiting body of $D$. tricolor, which was ligneous and longevous enough to feed and breed successfully in the woody fruiting body.

\section{Terminology}

Several ecological classifications exist for fungivorous insects, and we classify them into three main categories (Graves, 1960; Klimaszewski and Peck, 1987; Lawrence and Milner, 1996; Krasutskii, 2006), as follows: 1) Mycetobionts (MB) which are obligatory fungal inhabitants, feeding and breeding on the fungal host, 2) Mycetophiles (MP), which only feed on fungi at some point during their life, but do not require the fungus for development, and 3) Mycetoxenes (MX), which are found occasionally in and around fungi as a simple visitor for shelter.

Verified records are further divided into those which definitely represent a breeding population and those which may be accidental. The standard of mycetobionts, modified Lawrence (1973), consists of any one of the following: A) Larvae molt twice at least, B) All adults, larvae, and pupa are found in the same host fungi, or C) Five or more pupa or five or more adults are found.

By the nature of trophic associations based on Krasutskii (2006), specialized mycetobionts may be classified as follows: 1) Polyphagous species populating fungi of different classes; 2 ) Oligophagous species associated with fungi of a single family or several genus, and 3) Monophagous species narrowly specialized in relation to fungi belonging to a single genus or even species. 


\section{Identification of Fungi}

Host fungi collected for this study were identified using several illustrated mushroom books (Breitenbach and Kränzlin, 1986; Imazeki and Hongo, 1987, 1989; Lee, 1988; Kim et al., 2004) with the assistance of a mushroom taxonomist, Dr. Seok S. J..in the National Academy of Agricultural Science (NAAS).

\section{Results and Discussion}

A total of 31 Korean tenebrionid species from four tribes (Bolitiophagini, Toxicini, Scaphidemini, and Diaperini) were observed on 42 fungal hosts, including in the literature cited (Table 1). Almost all Korean fungivorous tenebrionids inhabit wood rotting fungi of the order Aphyllophorales and rarely of

Table 1. Checklist of the fungivorous tenebrionids and type of association with fungal hosts

\begin{tabular}{|c|c|c|c|c|c|c|}
\hline \multirow[t]{2}{*}{ Tenebrionid species } & \multirow[t]{2}{*}{ Fungal host } & \multirow{2}{*}{$\begin{array}{l}\text { No. of fungi } \\
\text { collected }\end{array}$} & \multicolumn{3}{|c|}{$\begin{array}{l}\text { No. of fungi in which } \\
\text { beetles bred }\end{array}$} & \multirow{2}{*}{$\begin{array}{l}\text { cate } \\
\text { gory }\end{array}$} \\
\hline & & & $\mathrm{A}$ & $\mathrm{B}$ & $\mathrm{C}$ & \\
\hline $\begin{array}{l}\text { Subfamily Tenebrioninae } \\
\text { Tribe Toxicini }\end{array}$ & & & & & & \\
\hline Cryphaeus duellicus (Lewis) & $\begin{array}{l}\text { Daedaleopsis congragosa } \\
\text { Daedaleopsis tricolor } \\
\text { Coriolus sp. }\end{array}$ & $\begin{array}{l}2 \\
3\end{array}$ & & $\begin{array}{l}1 \\
2\end{array}$ & $\begin{array}{l}1 \\
1\end{array}$ & $\begin{array}{l}\text { MB } \\
\text { MB } \\
\text { UN }\end{array}$ \\
\hline Cryphaeus punctatulus (Lewis) & $\begin{array}{l}\text { Daedaleopsis congragosa } \\
\text { Daedaleopsis tricolor }\end{array}$ & $\begin{array}{l}2 \\
2\end{array}$ & & $\begin{array}{l}1 \\
1\end{array}$ & $\begin{array}{l}1 \\
1\end{array}$ & $\begin{array}{l}\mathrm{MB} \\
\mathrm{MB}\end{array}$ \\
\hline Cryphaeus rotundicollis Chûjô et Lee & $\begin{array}{l}\text { Daedaleopsis congragosa } \\
\text { Daedaleopsis tricolor } \\
\text { Lampteromyces japonicus } \\
\text { Schizophyllum commune } \\
\text { Laepiporus sulphureus }\end{array}$ & $\begin{array}{c}11 \\
10 \\
1 \\
1 \\
1\end{array}$ & $\begin{array}{l}1 \\
1 \\
1\end{array}$ & $\begin{array}{l}8 \\
7\end{array}$ & $\begin{array}{l}2 \\
2\end{array}$ & $\begin{array}{l}\text { MB } \\
\text { MB } \\
\text { MP } \\
\text { MX } \\
\text { MX }\end{array}$ \\
\hline $\begin{array}{l}\text { Cryphaeus albopilosus Chûjô et Lee } \\
\text { Tribe Bolitophagini }\end{array}$ & Daedaleopsis sp. & 1 & & & & UN \\
\hline Boletoxenus bellicosus (Lewis) & $\begin{array}{l}\text { Fomes fomentarius }{ }^{4} \\
\text { Perenniporia frazinea } \\
\text { Perenniporia medulla-panis } \\
\text { Ganoderma lucidum } \\
\text { Fomitopsis pinicola }{ }^{6} \\
\text { Ganoderma } \text { sp. }^{4} \\
\text { Fomitopsis sp. }{ }^{12} \\
\text { Fomes } \mathrm{sp}^{12}{ }^{12}\end{array}$ & $\begin{array}{l}5 \\
1 \\
1 \\
1\end{array}$ & & 5 & 1 & $\begin{array}{l}\text { MB } \\
\text { MB } \\
\text { MP } \\
\text { MP } \\
\text { UN } \\
\text { UN } \\
\text { UN } \\
\text { UN }\end{array}$ \\
\hline Boletoxenus sp. & $\begin{array}{l}\text { Fomitopsis pinicola } \\
\text { Fomes fomentarius } \\
\text { Fomitopsis officinale }\end{array}$ & 1 & 1 & & & $\begin{array}{l}\text { MB } \\
\text { UN } \\
\text { UN }\end{array}$ \\
\hline Bolitophagus reticulatus (Linnaeus) & $\begin{array}{l}\text { Fomitopsis sp. }{ }^{1} \\
\text { Fomes fomentarius } 5 \\
\text { Daedaleopsis confragosa } \\
\text { Fomes sp. }\end{array}$ & & & & & $\begin{array}{l}\text { UN } \\
\text { UN } \\
\text { UN } \\
\text { UN }\end{array}$ \\
\hline Bolitophagiella pannosua (Lewis) & $\begin{array}{l}\text { Perenniporia frazinea } \\
\text { Perenniporia medulla-panis }\end{array}$ & $\begin{array}{c}30 \\
2\end{array}$ & & $\begin{array}{c}30 \\
2\end{array}$ & & $\begin{array}{l}\mathrm{MB} \\
\mathrm{MB}\end{array}$ \\
\hline Byrsax kimurai Miyatake & $\begin{array}{l}\text { Daedaleopsis tricolor } \\
\text { Bjerkandera adusta } \\
\text { Stereum sanguinolentum } \\
\text { Microporus vernicipes } \\
\text { Coriolus brevis } \\
\text { Fomitopsis sp. }{ }^{1} \\
\text { Fomes sp. }\end{array}$ & $\begin{array}{l}5 \\
6 \\
1 \\
6 \\
1\end{array}$ & & $\begin{array}{l}5 \\
5\end{array}$ & $\begin{array}{l}1 \\
2\end{array}$ & $\begin{array}{l}\text { MB } \\
\text { MB } \\
\text { MX } \\
\text { MB } \\
\text { MP } \\
\text { UN } \\
\text { UN }\end{array}$ \\
\hline
\end{tabular}


Table 1. Checklist of the fungivorous tenebrionids and type of association with fungal hosts (Continued)

\begin{tabular}{|c|c|c|c|c|c|c|}
\hline \multirow[t]{2}{*}{ Tenebrionid species } & \multirow[t]{2}{*}{ Fungal host } & \multirow{2}{*}{$\begin{array}{c}\text { No. of fungi } \\
\text { collected }\end{array}$} & \multicolumn{3}{|c|}{$\begin{array}{l}\text { No. of fungi in which } \\
\text { beetles bred }\end{array}$} & \multirow{2}{*}{$\begin{array}{l}\text { cate } \\
\text { gory }\end{array}$} \\
\hline & & & A & $\mathrm{B}$ & $\mathrm{C}$ & \\
\hline \multirow[t]{3}{*}{ Byrsax spiniceps Lewis } & Daedaleopsis tricolor & 6 & & 6 & & MB \\
\hline & Bjerkandera adusta & 9 & & 7 & 2 & MB \\
\hline & Coriolus brevis & 1 & & & & MP \\
\hline \multirow[t]{5}{*}{ Parabolitophagus felix (Lewis) } & Cryptoporus volvatus ${ }^{24}$ & 3 & & 2 & 1 & MB \\
\hline & Ganoderma lucidum ${ }^{4}$ & & & & & \\
\hline & Cryptoderma pin ${ }^{24}$ & & & & & \\
\hline & Fomitopsis sp. ${ }^{1}$ & & & & & UN \\
\hline & Fomes sp. ${ }^{1}$ & & & & & UN \\
\hline Bolitotrogus sp. & Inonotus mikadoi & 1 & & & 1 & MB \\
\hline \multicolumn{7}{|l|}{$\begin{array}{l}\text { Subfamily Diaperinae } \\
\text { Tribe Diaperini }\end{array}$} \\
\hline \multirow[t]{4}{*}{ Basanus tsushimensis M.T. Chûjô } & Mycoacia copelandii & 7 & & 7 & & MB \\
\hline & mycelia under the bark & 10 & & 2 & 7 & MB \\
\hline & Bjerkandera adusta & 1 & & & & MX \\
\hline & Hydnaceae sp.3 & & & & & UN \\
\hline \multirow[t]{5}{*}{ Ceropria laticollis Fairmaire } & Coriolus versicolor & 3 & 2 & 1 & & MB \\
\hline & mycelia under the bark & 10 & 3 & 6 & 1 & MB \\
\hline & Daedaleopsis congragosa & 1 & & & & MP \\
\hline & Daedaleopsis tricolor & 1 & & & & MP \\
\hline & Bjerkandera adusta & 1 & & & & MX \\
\hline \multirow[t]{10}{*}{ Ceropria induta induta (Wiedemann) } & Coriolus versicolor & 2 & & & 2 & MB \\
\hline & Coriolus unicolor & 2 & 1 & & 1 & MB \\
\hline & Daedaleopsis congragosa & 1 & & & 1 & MB \\
\hline & Daedaleopsis tricolor & 3 & & & 3 & MB \\
\hline & mycelia on the bark & 5 & 2 & 2 & 2 & MB \\
\hline & Bjerkandera adusta & 1 & & & & MX \\
\hline & Stereum gausapatum & 1 & & & & MP \\
\hline & Stereum hirsutum & 1 & & & & MP \\
\hline & Lentinellus ursinus & 2 & & & & MX \\
\hline & Coriolus sp. ${ }^{1}$ & & & & & UN \\
\hline \multirow[t]{3}{*}{ Ceropria sulcifrons Harold } & Coriolus versicolor & 2 & & & & MP \\
\hline & mycelia on the bark & 2 & & 1 & 1 & MB \\
\hline & Daedaleopsis tricolor & 1 & & & & MP \\
\hline \multirow[t]{9}{*}{ Ceropria striata Lewis } & Coriolus versicolor & 4 & & 4 & & MB \\
\hline & Coriolus unicolor & 4 & & 4 & & MB \\
\hline & Daedaleopsis tricolor & 3 & & & 3 & MB \\
\hline & Amillaria mellea (dried) & 2 & & & & MP \\
\hline & Cylindrobasidium evolvens & 2 & 1 & 1 & & MB \\
\hline & mycelia on the bark & 4 & 1 & 3 & & MB \\
\hline & Bjerkandera adusta & 1 & & & & MX \\
\hline & Schizophyllum commune & 1 & & & & MX \\
\hline & Coriolus sp. ${ }^{1}$ & & & & & UN \\
\hline \multirow[t]{3}{*}{ Diaperis lewisi lewisi Bates } & Laepiporus sulphureus & 15 & & 15 & & MB \\
\hline & Coriolus sp. ${ }^{1}$ & & & & & UN \\
\hline & Lentinus lepideus & & & & & UN \\
\hline \multirow[t]{5}{*}{ Platydema recticorne Lewis } & Lentinellus ursinus & 1 & & & & MP \\
\hline & Coriolus versicolor & 1 & & & & MX \\
\hline & mycelia on the bark & 2 & & & 1 & MB \\
\hline & Coriolus unicolor & 1 & & & & MX \\
\hline & Trametes gibbosa & 1 & & & & MP \\
\hline
\end{tabular}


Table 1. Checklist of the fungivorous tenebrionids and type of association with fungal hosts (Continued)

\begin{tabular}{|c|c|c|c|c|c|c|}
\hline \multirow[t]{2}{*}{ Tenebrionid species } & \multirow[t]{2}{*}{ Fungal host } & \multirow{2}{*}{$\begin{array}{c}\text { No. of fungi } \\
\text { collected }\end{array}$} & \multicolumn{3}{|c|}{$\begin{array}{l}\text { No. of fungi in which } \\
\text { beetles bred }\end{array}$} & \multirow{2}{*}{$\begin{array}{l}\text { cate } \\
\text { gory }\end{array}$} \\
\hline & & & A & $\mathrm{B}$ & $\mathrm{C}$ & \\
\hline & Daedaleopsis congragosa & 5 & & 4 & 1 & MB \\
\hline & Heterobasidion insularis & 3 & & 3 & & MB \\
\hline & Laepiporus sulphureus & 3 & & 1 & 2 & MB \\
\hline & Cylindrobasidium evolvens & 1 & & & & MX \\
\hline & Amillaria mellea (dried) & 1 & & 1 & & MP \\
\hline & Daedaleopsis tricolor & 20 & & 18 & 2 & MB \\
\hline & Trametes sp. & 1 & & 1 & & MB \\
\hline & Merulius tremellosus & 3 & & 1 & 2 & MB \\
\hline & Bjerkandera adusta & 7 & & 5 & 2 & MB \\
\hline & Phaeolus schweinitzii & 2 & & 2 & & MB \\
\hline \multirow[t]{4}{*}{ Platydema subfascia subfascia (Walker) } & Inonotus radiatus & 2 & & 2 & & MB \\
\hline & Coriolus unicolor & 1 & & & & MP \\
\hline & Inonotus sp. & 1 & & & 1 & MB \\
\hline & Daedaleopsis tricolor & 2 & & 1 & & MB \\
\hline \multirow[t]{4}{*}{ Platydema fumosum Lewis } & Lentinellus ursinus & 1 & & & & MX \\
\hline & Daedaleopsis tricolor & 5 & & 5 & & MB \\
\hline & Daedaleopsis congragosa & 4 & & 4 & & MB \\
\hline & Bjerkandera adusta & 1 & & & & MX \\
\hline Platydema lynceum Lewis & mycelia on the bark & 1 & & & & UN \\
\hline Platydema kurama Nakane & mycelia on the bark & 1 & & & & UN \\
\hline \multirow[t]{13}{*}{ Platydema nigroaeneum Motschulsky } & Lentinellus ursinus & 1 & & & & MP \\
\hline & Coriolus versicolor & 3 & & & 1 & MB \\
\hline & Coriolus unicolor & 2 & & & 2 & MB \\
\hline & Daedaleopsis congragosa & 3 & & 3 & & MB \\
\hline & Amillaria mellea (dried) & 1 & & & & MP \\
\hline & Daedaleopsis tricolor & 30 & & 25 & 5 & MB \\
\hline & Coriolus brevis & 4 & 2 & & 2 & MB \\
\hline & Merulius tremellosus & 5 & & 5 & & MB \\
\hline & Stereum gausapatum & 2 & 1 & 1 & & MB \\
\hline & Bjerkandera adusta & 15 & 5 & 10 & & MB \\
\hline & Trametes hirsuta & 1 & & 1 & & MB \\
\hline & Coriolus sp. ${ }^{1}$ & & & & & UN \\
\hline & Lampteromyces japonicus & 1 & 1 & & & MB \\
\hline Platydema koreanum Chûjô & Daedaleopsis tricolor & 2 & 1 & 1 & & MB \\
\hline Platydema marseuli Lewis & Daedaleopsis tricolor & 2 & 1 & 1 & & MB \\
\hline Platydema sp. & Stereum hirsutum & 4 & & 4 & & MB \\
\hline Ischnodactylus loripes Lewis & Cryptoporus volvatus $^{2}$ & & & & & UN \\
\hline Ischnodactylus sp. & Trametes sp. & 1 & & 1 & & MB \\
\hline \multicolumn{7}{|l|}{ Tribe Scaphidemini } \\
\hline Scaphidema michihidei Chûjô and Lee & mycelia in the bark & 1 & & 1 & & UN \\
\hline Scaphidema kayokoae Chûjô & mycelia in the bark & 1 & & 1 & & UN \\
\hline
\end{tabular}

1. Category (type of association) indicates that the beetle is an obligate/mycetobiont (MB), a facultative/mycetophile (MP), an accidental/mycetoxene (MX), or an unknown association (UN).

2. "A", "B" or "C" indicates the standard type of mycetobionts whether the beetles breed or not: A) larvae molt twice at least, B) all of adults, larvae, and pupa are found in the same host fungi, C) five or more pupa, and five or more adults are found.

3. Superscript numbers refer to the source data from Japan and Russia.

${ }^{1}$ Chujo, 1992;

${ }^{2}$ Hayashi, 1966;

${ }^{3}$ Kompantseva, 1985;

${ }^{4}$ Miyatake, 1964;

${ }^{5}$ Nadvaornaya and Nadvornyy, 1991. 
the order Agaricales (mushrooms and other gilled fungi). We observed that tenebrionids dominantly appeared to be more host-specific on the fruiting bodies of Aphyllopharales than those of Agaricales.

Among the fungal host species where tenebrionids were collected, approximately 94 percent belong to Aphyllophorales group which are woody and longevous. The high degree of host specificity of tenebrionid beetles living in wood rotting fungi could be explained by the long life span of the fruiting bodies (six months to three years). Most tenebrionids have obligatorily inhabited wood rotting fungi for all their lives, thus they are ecologically categorized as mycetobionts. Meanwhile, only four species (Lampteromyces japonicus, Schizophyllum commune, Amillaria mellea, Lentinellus ursinus) belonging to Agaricales group provide tenebrionids with incidental shelter and a fungal diet.

Fungal hosts play a role for the Korean fungivorous tenebrionids as follows (except for the literature cited): Approximately 62 percent of the total fungal hosts provide the tenebrionids with feeding and breeding habitats (mycetobionts), 13 percent provide them with only feeding diets (mycetophiles), 19 percent provide them with shelters (mycetoxenes), and 6 percent comprised undefined or uncertain habitats.

Diaperini was the most common tenebrionids associated with fungi: 17 species of Diaperini associated with total 28 fungal host species, 12 species of Bolitophagini with 17 fungal host species, four species of Toxicini with 7 fungal host species, and two species Scaphidemini collected mycelia in the bark.

Some Korean fungivorous tenebrionids are observed as monophagous species, which included 10 species (Cryphaeus duellicus, C. rotundicollis, C. punctatulus, Boletoxenus bellicosus, Bolitophagiella pannosa, Parabolitophagus felix, Diaperis lewisi lewisi, Platydema fumosum, Platydema higonium, Boletoxenus sp. ). Both the larvae and adults of the monophagous species feed and breed on the fruiting body of limited fungal hosts, being narrowly specialized to a single genus or species. 14 tenebrionids were observed as polyphagous species populating fungi of different genus and families. Finally, seven tenebrionids are of uncertain species because the records cited have little information on fungal hosts and short of collecting.

\section{Acknowledgements}

This work was supported by the National Research Foundation of Korea Grant funded by the Korean Government(Ministry of Education, Science and Technology). [NRF-2010-355- C00092]

\section{Literature Cited}

Benick, L. 1952. Pilzkäfer und Käferpilze. Acta Zool. Fennica 70: 1-250.

Breitenbach, J. and F. Kränzlin. 1986. Fungi of Switzerland, Volume 2 Non gilled fungi (Heterobasidiomycetes, Aphyllophorales, Gastromycetes). 412 pp. Verlag Mykologia, Switzerland.

Chŭjô, M.T. 1992. Fungivorous Tenebrionidae. Insects \& Nature 27(13): 9-14.

Cline, A.R. and Leschen R.B. 2005. Coleoptera associated with the oyster mushroom, Pleurotus ostreatus Fries, in North America. Southeastern Naturalist 4(3): 409-420.

Graves, R.C. 1960. Ecological observations on the insects and other inhabitants of woody shelf fungi (Basidiomycetes: Polyporaceae) in the Chicago area. Ann. Entomol. Soc. Am. 53: 61-78.

Hayashi, N. 1966. A contribution to the knowledge of the larvae of Tenebrionidae occurring in Japan. Insecta Matsumurana 1: 1-41.

Heatwole, H. and A. Heatwole. 1968. Movements, host-fungus preferences, and longevity of Bolitotherus cornutus (Coleoptera: Tenebrionidae). Ann. Entomol. Soc. Am. 61: 18-23.

Imazeki, R. and T. Hongo. 1987. Colored Illustrations of Mushrooms of Japan Vol. I. 325 pp. Hiokusha publishing co., Ltd, Japan.

Imazeki, R. and T. Hongo. 1989. Colored Illustrations of Mushrooms of Japan Vol. II. 315 pp. Hiokusha publishing co., Ltd, Higashiosaka, Japan.

Jung, B.H., S.Y. Kim and J.I. Kim. 2007. Taxonomic review of the tribe Bolitophagini in Korea (Coleoptera: Tenebrionidae: Tenebrioninae). Entomol. Res. 37: 190-196.

Jung, B.H. and J.I. Kim. 2008. Biology of Platydema nigroaeneum Motschulsky (Coleoptera: Tenebrionidae) from Korea: Life History and Fungal Hosts. J. Ecol. Field Biol. 31(3): 249-253.

Jung B.H. and J.I. Kim. 2009. Biology of Bolitophagiella pannosa (Lewis) newly reported from Korea (Coleoptera: Tenebrionidae). Kor. J. Appl. Entomol. 48(2): 159-164.

Jung, B.H., S.Y. Kim and J.I. Kim. 2009. Taxonomic review of the genus Cryphaeus Klug, 1833 (Coleoptera: Tenebrionidae: Toxicini) in Korea and description of new host fungi. J. Asia-Pacific Entomol. 12(4): 241-246.

Kim Y.S., S.J. Seok, H.Y. Won, K.H. Lee, W.K. Lee and J.S. Park. 2004. The mushrooms of Korea. National institute of Agricultural Science and Technology Rural Development Administration. 467 pp. Dongbang media, Seoul. 
Klimaszewski, J. and S.B. Peck. 1987. Sucession and phenology of beetles faunas (Col.) in the fungus Polyporellus Squamoxs (Huds.: Fr.) Karst. (Polyporaceae) in Silesia, Poland. Can. J. Zool. 65: 542-550.

Kompantseva, T.V. 1985. Description of the larva and biological peculiarities of the Tenebrionid beetle Basanus tsushimensis Kompancevi Kaszab et G. Medvedev (Coleoptera, Tenebropnidae) from Southern Priomorye Territory. Entomol. Obozrenie 64(2): 364-369 (in Russian).

Krasutskii, B.V. 2006. Beetles (Coleoptera) Associated with the Polypore Daedaleopsis congragosa (Bolton: Fr.) J. Schrot (Basidiomycetes, Aphyllophorales) in Forests of the Urals and Transurals. Entomol. Rev. 87(5): 512-523.

Lawrence, J.F. 1973. Host preference in ciid beetles (Col.: Ciidae) inhabiting the fruiting bodies of Basidiomycetes in North America. Bull. Mus. Comp. Zool. 145(3): 163-212.

Lawrence, J.F. and R. J. Milner. 1996. Associations between arthropods and fungi. Fungi Aust. 1B: 137-202.

Lee, J. Y. 1988. Colored Korean Mushrooms (I). 365 pp. Academy, Seoul.
Leschen, R.A.B. 1990. Tenebrionoid-Basidiomycete relationships with comments on feeding ecology and the evolution of fungal mycophagy (Col. Hymenomycetes). Univ. Kansas Sci. Bull. 54: 165-177.

Liles, M. 1956. A study of the life history of the forked fungus beetle, Bolitotherus cornutus (Panzer) (Coleoptera: Tenebrionidae). Ohio J. Sci. 56(6): 329-337.

Matthewman, R.H. and D.P. Pielow. 1971. Arthropods inhabiting the sporophores of Fomes fomentarius (Polyporaceae) in Gatineau Park, Quebec. Can. entomol. 103: 775-847.

Miyatake, M. 1964. Notes on the tribe Bolitophagini of Japan, with the descriptions of four new genera and two new species (Coleoptera: Tenebrionidae). Trans. Shikoku Entomol. Soc. 8(2): 59-84.

Nadovornaya L.S and V.G. Nadvornyy. 1991. Biology th the Darkling beetles Bolitophagus reticulatus L. and Uloma culinaris L. (Coleoptera: Tenebrionidae) in the Forest Steppe Zone of the Ukraine. Entomol. Obozeniye 2: 349-354 (In Russian).

Nikitsky, N.B. and D.S. Schigel. 2004. Beetles in polypores of the Moscow region: checklist and ecological notes. Entomol. Fennica 15: 6-22. 